\title{
Enantiospecific total synthesis of (+)-lentiginosine
}

\author{
Kavirayani R. Prasad* and Amit B. Pawar \\ Department of Organic Chemistry, Indian Institute of Science \\ Bangalore, India 560012 \\ E-mail:prasad@orgchem.iisc.ernet.in
}

\section{Dedicated to Professor Franklin A Davis on the occasion of his $\mathbf{7 0}^{\text {th }}$ birthday}

\begin{abstract}
A facile synthesis of (+)-lentiginosine is accomplished from L-(+)-tartaric acid. Key transformations in the synthesis include the elaboration of $\gamma$-oxo amide derived from tartaric acid.
\end{abstract}

Keywords: Lentiginosine, aza-sugar, stereoselective synthesis, tartaric acid

\section{Introduction}

(+)-Lentiginosine 1, was isolated in 1990 from the leaves of Astragalus lentiginosus and is the least hydroxylated naturally occurring indolizidine derivative, possessing potent amyloglucosidase inhibition activity. ${ }^{1}$ Owing to the growing interest in hydroxylated indolidizines as different glycosidase inhibitors, there has been a plethora of publications concerning the synthesis of hydroxylated indolidizines including lentiginosine. ${ }^{2}$ Reently, we demonstrated the versatility of $\gamma$-oxo-amides derived from tartaric acid in the synthesis of a variety of natural products. ${ }^{3}$ Herein, we report the application of these amides derived from L$(+)$-tartaric acid in the synthesis of (+)-lentiginosine.

\section{Results and Discussion}

Our approach for the synthesis of (+)-1, is based on the reduction of the lactam 9 to (+)-1. Formation of the lactam $\mathbf{9}$, was anticipated by reduction of the azide 5 followed by cyclization. $\gamma$ Hydroxy amide 4 was identified as the suitable precursor for the synthesis of $\mathbf{5}$. Synthesis of similar amides by controlled addition of Grignard reagent to the bis-dimethyl amide $\mathbf{2}$ followed by stereoselective reduction is a transformation that was optimized in our laboratory (Scheme-1). 


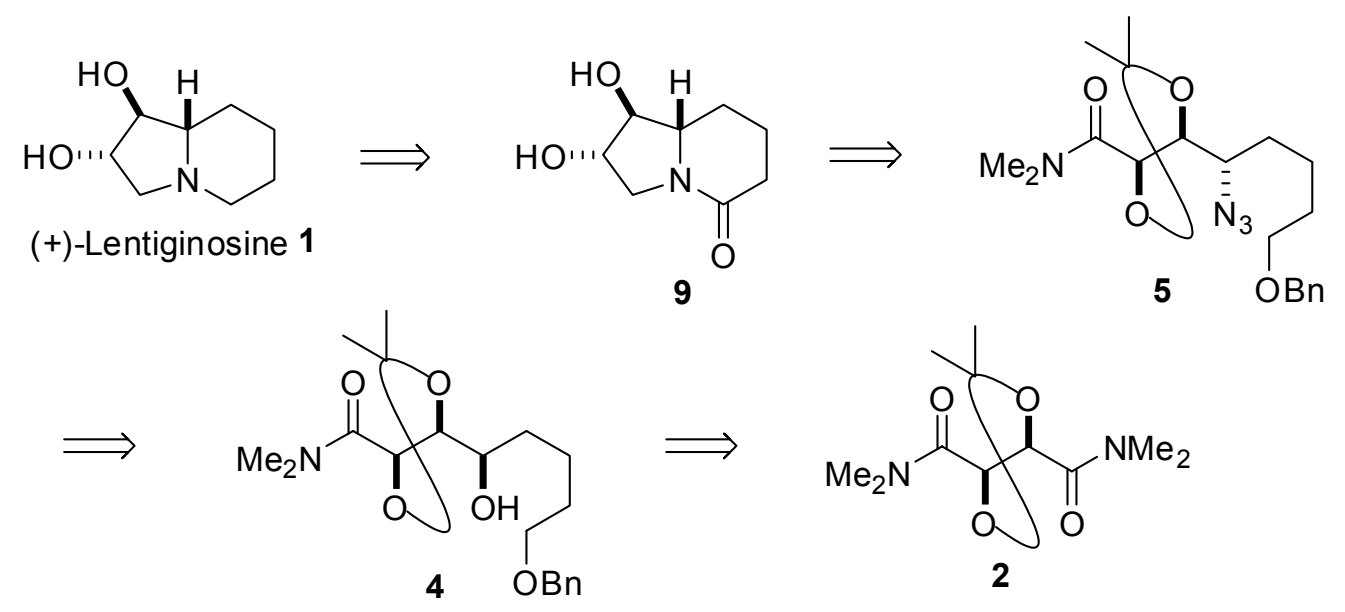

Scheme 1. Retrosynthesis for (+)-lentiginosine.

Accordingly, controlled addition of 4-benzyloxybutylmagnesium bromide to the bisdimethylamide 2 afforded the ketoamide 3 in $88 \%$ yield. ${ }^{4}$ Reduction of the keto group in 3 with $\mathrm{NaBH}_{4} / \mathrm{CeCl}_{3}$ furnished the alcohol as a 91:9 mixture of non-separable diastereomers in $71 \%$ yield with 4 being the major diastereomer. Conversion of the alcohol 4 to the corresponding mesylate, followed by reaction of the mesylate with sodium azide produced the secondary azide 5 in $85 \%$ yield. Deprotection of the acetonide in $\mathbf{5}$ furnished the hydroxyazide, which was subjected to hydrogenation without further purification in the presence of $\operatorname{Pd}(\mathrm{OH})_{2}$ to yield the pure diastereomeric lactam 6 in 60\% yield after column chromatography. ${ }^{5}$ Treatment of 6 with TBDMSOTf in presence of pyridine produced the corresponding bis-silylether in $92 \%$ yield, which on hydrogenation over $\mathrm{Pd} / \mathrm{C}$ furnished 7 in $91 \%$ yield. Transformation of the primary hydroxy group in 7 to the corresponding mesylate, and subsequent treatment with $\mathrm{NaH}$ produced the bicyclic lactam 8 in $72 \%$ yield. Deprotection of the silylether afforded the dihydroxylactam 9 in $82 \%$ yield, which on reaction with $\mathrm{LiAlH}_{4}$ prduced (+)-lentiginosine 1 in $87 \%$ yield. The physical spectral data of $\mathbf{1}$ is in complete agreement with that reported in the literature. ${ }^{2 \mathrm{j}}$

\section{Conclusions}

In summary, a facile enantiospecific synthesis of $(+)$-lentiginosine has been accomplished from the bis-dimethylamide of tartaric acid. The synthetic sequence depicted is high yielding and amenable to the synthesis of a number of analogues. 

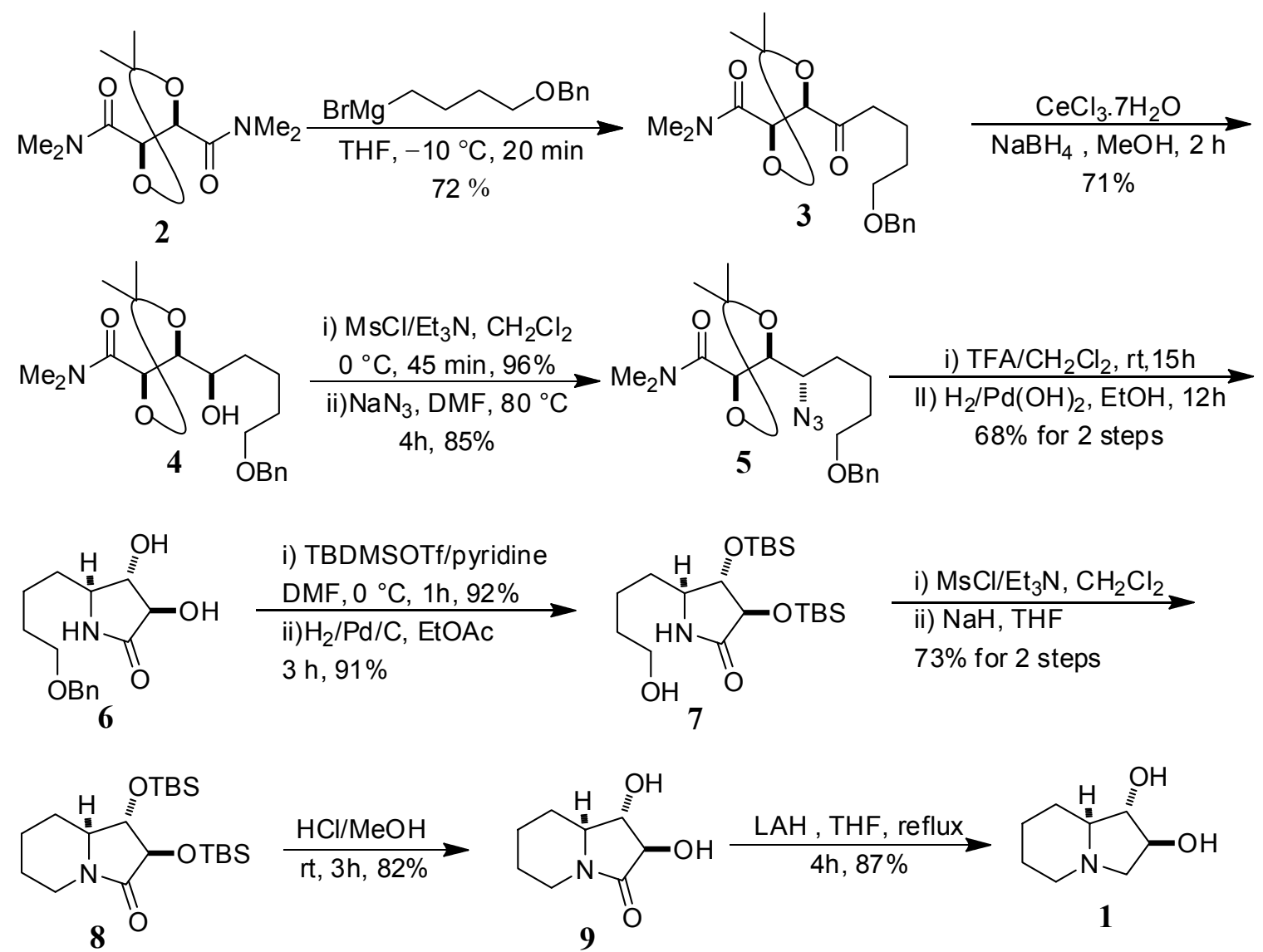

$\underset{4 \mathrm{~h}, 87 \%}{\stackrel{\mathrm{LAH}, \mathrm{THF}, \text { reflux }}{\longrightarrow}}$

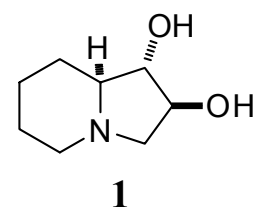

Scheme 2. Total synthesis of (+)-lentiginosine.

\section{Experimental Section}

Preparation of $(4 R, 5 R)-5-(5-(b e n z y l o x y) p e n t a n o y l)-N, N, 2,2$-tetramethyl-1,3-dioxolane-4carboxamide 3. In a two-necked, $100 \mathrm{~mL}$, round-bottomed flask equipped with a magnetic stirring bar, rubber septum, and argon inlet was placed 2 (1.0 g, $4.1 \mathrm{mmol})$. This was dissolved in $10 \mathrm{~mL}$ of THF and the solution was cooled to $-10{ }^{\circ} \mathrm{C}$. A freshly prepared THF solution of 4benzyloxybutylmagnesium bromide ( $9 \mathrm{~mL}$ of $0.7 \mathrm{M}$ solution in THF, $6.3 \mathrm{mmol}$ ) was added at such a rate that the internal temperature did not rise above $-10{ }^{\circ} \mathrm{C}$. Progress of the reaction was monitored by TLC and after the reaction was complete $(\sim 0.5 \mathrm{~h})$, it was cautiously quenched by addition of saturated solution of $\mathrm{NH}_{4} \mathrm{Cl}(10 \mathrm{~mL})$. The mixture was then poured into water $(20$ $\mathrm{mL})$ and extracted with ether $(3 \times 25 \mathrm{~mL})$. Combined ethereal extracts were washed with brine $(30 \mathrm{~mL})$ and dried $\left(\mathrm{Na}_{2} \mathrm{SO}_{4}\right)$. Evaporation of the solvent and silica gel column chromatography of the residue with petroleum ether:EtOAc (6:4) as eluent yielded $\mathbf{3}(1.07 \mathrm{~g}, 72 \%)$ as a colorless oil. $[\alpha]_{\mathrm{D}}+8.5\left(\mathrm{c} 1.0, \mathrm{CHCl}_{3}\right.$ ); IR (neat) $2937,2863,1714,1650,1377,1098,738 \mathrm{~cm}^{-1}$; ${ }^{1} \mathrm{H} \mathrm{NMR}$ $\left(300 \mathrm{MHz}, \mathrm{CDCl}_{3}\right) \delta$ 7.35-7.26 (m, 5H), $5.14(\mathrm{~d}, J=5.7 \mathrm{~Hz}, 1 \mathrm{H}), 4.79(\mathrm{~d}, J=5.7 \mathrm{~Hz}, 1 \mathrm{H}), 4.49$ 
(s, 2H), $3.48(\mathrm{t}, J=5.7 \mathrm{~Hz}, 2 \mathrm{H}), 3.13(\mathrm{~s}, 3 \mathrm{H}), 3.00(\mathrm{~s}, 3 \mathrm{H}), 2.81-2.58(\mathrm{~m}, 2 \mathrm{H}), 1.73-1.60(\mathrm{~m}, 4 \mathrm{H})$, $1.42(\mathrm{~s}, 6 \mathrm{H}) ;{ }^{13} \mathrm{C}$ NMR $\left(75 \mathrm{MHz}, \mathrm{CDCl}_{3}\right) \delta 209.0,168.2,138.6,128.3,127.6,127.5,112.1,82.1$, 75.0, 72.9, 70.0, 39.2, 37.0, 36.0, 29.1, 26.4, 26.1, 19.9; HRMS for $\mathrm{C}_{20} \mathrm{H}_{29} \mathrm{NO}_{5}+\mathrm{Na}$ calcd 386.1943 ; found 386.1942 .

Preparation of $(4 R, 5 S)-5-((R)-5-(b e n z y l o x y)-1-h y d r o x y p e n t y l)-N, N, 2,2-t e t r a m e t h y l-1,3-$ dioxolane-4-carboxamide 4 . To a solution of $3(0.8 \mathrm{~g}, 2.2 \mathrm{mmol})$ in methanol $(8 \mathrm{~mL})$ was added $\mathrm{CeCl}_{3} .7 \mathrm{H}_{2} \mathrm{O}(1.2 \mathrm{~g}, 3.3 \mathrm{mmol})$ at room temperature and the mixture was stirred at the same temperature for $1 \mathrm{~h}$. It was then cooled to $-78{ }^{\circ} \mathrm{C}$ and $\mathrm{NaBH}_{4}(0.12 \mathrm{~g}, 3.3 \mathrm{mmol})$ was added portionwise over a period of $20 \mathrm{~min}$ and the mixture stirred at $-78{ }^{\circ} \mathrm{C}$. After the completion of the reaction (TLC) it was cautiously quenched by addition of water $(10 \mathrm{~mL})$ and extracted with EtOAc $(3 \times 25 \mathrm{~mL})$. The combined organic layers were washed with brine $(30 \mathrm{~mL})$, dried over $\mathrm{Na}_{2} \mathrm{SO}_{4}$, and concentrated. Silica gel column chromatography of the crude residue, with petroleum ether:EtOAc (1:1) as eluent, gave 4 (diastereomeric mixture 91:9) $(0.57 \mathrm{~g}, 71 \%)$ as a viscous liquid. $[\alpha]_{\mathrm{D}}-10.9$ (c 1.7, $\mathrm{CHCl}_{3}$ ); IR (neat) 3448, 2987, 2864, 1651, 1497, 1381, $1071 \mathrm{~cm}^{-1} ;{ }^{1} \mathrm{H}$ NMR (400 MHz, $\left.\mathrm{CDCl}_{3}\right) \delta$ 7.36-7.23 (m, 5H), 4.58-4.50 (m, 2H), $4.49(\mathrm{~s}, 2 \mathrm{H})$, 3.62-3.54 (m, 1H), $3.47(\mathrm{t}, J=6.2 \mathrm{~Hz}, 2 \mathrm{H}), 3.12(\mathrm{~s}, 3 \mathrm{H}), 2.95(\mathrm{~s}, 3 \mathrm{H}), 2.13-2.08(\mathrm{~m}, 1 \mathrm{H}), 1.68-$ $1.53(\mathrm{~m}, 4 \mathrm{H}), 1.44(\mathrm{~s}, 3 \mathrm{H}), 1.38(\mathrm{~s}, 3 \mathrm{H}) ;{ }^{13} \mathrm{C} \mathrm{NMR}\left(100 \mathrm{MHz}, \mathrm{CDCl}_{3}\right) \delta 169.0,138.5,128.3$, 127.6, 127.4, 110.2, 80.2, 74.2, 72.9, 70.2, 69.9, 37.0, 35.7, 34.5, 29.5, 26.8, 26.1, 22.6; HRMS for $\mathrm{C}_{20} \mathrm{H}_{31} \mathrm{NO}_{5}+\mathrm{Na}$ calcd 388.2100; found 388.2102.

Preparation of $\quad(4 R, 5 S)-5-((S)-1-a z i d o-5-(b e n z y l o x y) p e n t y l)-N, N, 2,2-t e t r a m e t h y l-1,3-$ dioxolane-4-carboxamide 5. To a solution of $4(0.5 \mathrm{~g}, 1.4 \mathrm{mmol})$ in dry $\mathrm{CH}_{2} \mathrm{Cl}_{2}(8 \mathrm{~mL})$ were added $\mathrm{Et}_{3} \mathrm{~N}(0.3 \mathrm{~mL}, 2.1 \mathrm{mmol})$ and methanesulfonyl chloride $(0.16 \mathrm{~mL}, 2.1 \mathrm{mmol})$ at $0{ }^{\circ} \mathrm{C}$ and the mixture was stirred at the same temperature. The progress of the reaction was monitored by TLC. After the reaction was complete ( $45 \mathrm{~min})$, it was quenched by addition of water $(10 \mathrm{~mL})$. The mixture was then extracted with $\mathrm{CH}_{2} \mathrm{Cl}_{2}(3 \times 15 \mathrm{~mL})$ and the combined organic extracts were washed with brine $(25 \mathrm{~mL})$ and dried over anhydrous $\mathrm{Na}_{2} \mathrm{SO}_{4}$. Evaporation of solvent and silica gel column chromatography of the resulting residue with petroleum ether:EtOAc $(6: 4)$ as eluent gave the corresponding mesylate $(0.58 \mathrm{~g}, 96 \%)$ as a colorless oil. $[\alpha]-8.7\left(c 0.8, \mathrm{CHCl}_{3}\right)$; IR (neat) 2935, 2859, 1651, 1455, 1353, $1215 \mathrm{~cm}^{-1} ;{ }^{1} \mathrm{H}$ NMR $\left(300 \mathrm{MHz}, \mathrm{CDCl}_{3}\right) \delta$ 7.35-7.26 (m, $5 \mathrm{H}), 4.85-4.73(\mathrm{~m}, 2 \mathrm{H}), 4.53-4.49(\mathrm{~m}, 1 \mathrm{H}), 4.48(\mathrm{~s}, 2 \mathrm{H}), 3.48(\mathrm{t}, J=6.0 \mathrm{~Hz}, 2 \mathrm{H}), 3.12(\mathrm{~s}, 3 \mathrm{H})$, $3.10(\mathrm{~s}, 3 \mathrm{H}), 3.0(\mathrm{~s}, 3 \mathrm{H}), 1.85-1.51(\mathrm{~m}, 6 \mathrm{H}), 1.45(\mathrm{~s}, 3 \mathrm{H}), 1.37(\mathrm{~s}, 3 \mathrm{H}) ;{ }^{13} \mathrm{C} \mathrm{NMR}(75 \mathrm{MHz}$, $\left.\mathrm{CDCl}_{3}\right) \delta 168.0,138.5,128.3,127.6,127.5,110.8,81.6,78.2,74.3,72.9,70.0,38.8,37.0,35.8$, 31.5, 29.2, 26.5, 26.1, 22.1; HRMS for $\mathrm{C}_{21} \mathrm{H}_{33} \mathrm{NO}_{7} \mathrm{~S}+\mathrm{Na}$ calcd 466.1875; found 466.1884.

To a solution of the mesylate obtained above $(0.52 \mathrm{~g}, 1.17 \mathrm{mmol})$ in dry DMF $(4 \mathrm{~mL})$ was added $\mathrm{NaN}_{3}(0.3 \mathrm{~g}, 4.7 \mathrm{mmol})$. The reaction mixture was stirred at $80^{\circ} \mathrm{C}$ for $4 \mathrm{~h}$. It was then poured into water $(15 \mathrm{~mL})$ and extracted with EtOAc $(3 \times 15 \mathrm{~mL})$. The combined organic extracts were washed with brine $(20 \mathrm{~mL})$ and dried over $\mathrm{Na}_{2} \mathrm{SO}_{4}$. The solvent was removed under reduced pressure and the residue thus obtained was purified by silica gel column chromatography using petroleum ether:EtOAc $(7: 3)$ as eluent to give $5(0.39 \mathrm{~g}, 85 \%)$ as a colorless oil. $[\alpha]_{\mathrm{D}}-73.3(c$ 
1.1, $\mathrm{CHCl}_{3}$ ); IR (neat) 3031, 2989, 2864, 2103, 1652, 1456, $1263 \mathrm{~cm}^{-1} ;{ }^{1} \mathrm{H} \mathrm{NMR} \mathrm{(300} \mathrm{MHz,}$ $\left.\mathrm{CDCl}_{3}\right) \delta 7.35-7.25(\mathrm{~m}, 5 \mathrm{H}), 4.86(\mathrm{dd}, J=6.3,4.2 \mathrm{~Hz}, 1 \mathrm{H}), 4.52(\mathrm{~d}, J=6.3 \mathrm{~Hz}, 1 \mathrm{H}), 4.5(\mathrm{~s}, 2 \mathrm{H})$, 3.72-3.65 (m, 1H). $3.47(\mathrm{t}, J=6.3 \mathrm{~Hz}, 2 \mathrm{H}), 3.15(\mathrm{~s}, 3 \mathrm{H}), 2.96(\mathrm{~s}, 3 \mathrm{H}), 1.72-1.52(\mathrm{~m}, 6 \mathrm{H}), 1.49(\mathrm{~s}$, $3 \mathrm{H}), 1.34(\mathrm{~s}, 3 \mathrm{H}) ;{ }^{13} \mathrm{C} \mathrm{NMR}\left(75 \mathrm{MHz}, \mathrm{CDCl}_{3}\right) \delta 169.0,138.5,128.3,127.6,127.4,110.5,79.9$, $73.9,72.9,70.3,63.4,37.1,35.9,30.6,29.3,26.5,25.8,25.2$; HRMS for $\mathrm{C}_{20} \mathrm{H}_{30} \mathrm{~N}_{4} \mathrm{O}_{4}+\mathrm{Na}$ calcd 413.2165; found 413.2164.

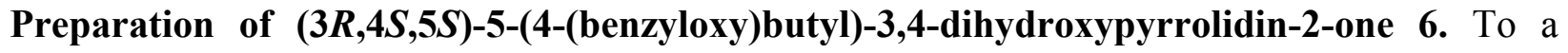
pre-cooled $\left(0^{\circ} \mathrm{C}\right)$ solution of $5(0.37 \mathrm{~g}, 0.95 \mathrm{mmol})$ in $\mathrm{CH}_{2} \mathrm{Cl}_{2}: \mathrm{H}_{2} \mathrm{O}(2: 0.2 \mathrm{~mL})$ was added drop wise TFA $(1 \mathrm{~mL})$ and was gradually warmed up to room temperature. It was stirred at the same temperature for $15 \mathrm{~h}$ and was cooled to $0^{\circ} \mathrm{C}$ and cautiously quenched by addition of solid $\mathrm{NaHCO}_{3}$ until the effervescence ceased. It was then filtered through a short pad of celite. The celite pad was washed with chloroform $(25 \mathrm{~mL})$. Evaporation of the solvent yielded the crude dihydroxyazidoamide, which was subjected to the next reaction without further purification.

To The solution of crude dihydroxyazidoamide, in $8 \mathrm{~mL}$ of absolute ethanol was added $\mathrm{Pd}(\mathrm{OH})_{2} / \mathrm{C}(100 \mathrm{mg})$. The reaction mixture was stirred for $12 \mathrm{~h}$ under hydrogen atmosphere (balloon) at the same temperature. The reaction mixture was filtered through a short pad of celite and the celite pad was washed with chloroform $(15 \mathrm{~mL})$. Evaporation of solvent followed by column chromatography of the residue using chloroform: methanol (9:1) gave 6 (0.18 g, $68 \%$ ) as a white solid. mp 113-114 ${ }^{\circ} \mathrm{C}$; $[\alpha]_{\mathrm{D}}-11.0$ (c 0.4, MeOH) ; IR (KBr) 3294, 3031, 2926, 2861, 1701, 1454, $1094 \mathrm{~cm}^{-1} ;{ }^{1} \mathrm{H}$ NMR $\left(300 \mathrm{MHz}, \mathrm{CDCl}_{3}\right) \delta 7.35-7.22(\mathrm{~m}, 5 \mathrm{H}), 7.11(\mathrm{bs}, 1 \mathrm{H}), 4.45(\mathrm{~s}$, $2 \mathrm{H}), 4.27(\mathrm{~d}, J=7.5 \mathrm{~Hz}, 1 \mathrm{H}), 3.80(\mathrm{t}, J=7.2 \mathrm{~Hz}, 1 \mathrm{H}), 3.44(\mathrm{t}, J=6.3 \mathrm{~Hz}, 2 \mathrm{H}), 3.27-3.22(\mathrm{~m}$, $1 \mathrm{H}), 1.66-1.38(\mathrm{~m}, 6 \mathrm{H}) ;{ }^{13} \mathrm{C} \mathrm{NMR}\left(75 \mathrm{MHz}, \mathrm{CDCl}_{3}\right) \delta 175.2,138.3,128.3,127.7,127.5,79.7$, 76.4, 72.8, 70.0, 56.8, 33.2, 29.4, 22.4; Analysis calcd for C $64.50 \mathrm{H} \mathrm{7.58} \mathrm{N} \mathrm{5.01;} \mathrm{found} \mathrm{C} 64.51$ $\mathrm{H} 7.62$ N 5.31; HRMS for $\mathrm{C}_{15} \mathrm{H}_{21} \mathrm{NO}_{4}+\mathrm{Na}$ calcd 302.1368; found 302.1365.

Praparation of (3R,4S,5S)-5-(4-hydroxybutyl)-3,4-Bis[ (tert-butyldimethylsilyl)oxy] pyrrolidin-2-one 7 . To the pre-cooled $\left(0^{\circ} \mathrm{C}\right)$ solution of $6(0.15 \mathrm{~g}, 0.53 \mathrm{mmol})$ in dry DMF $(3$ $\mathrm{mL})$ was added pyridine $(0.13 \mathrm{~mL}, 1.6 \mathrm{mmol})$ and TBDMSOTf $(0.36 \mathrm{~mL}, 1.6 \mathrm{mmol})$ and stirred for $1 \mathrm{~h}$ at the same temperature. After completion of the reaction (TLC) the mixture was poured into water $(15 \mathrm{~mL})$ and extracted with ether $(3 \times 15 \mathrm{~mL})$. Combined ethereal extracts were washed with brine $(20 \mathrm{~mL})$ and dried over anhydrous $\mathrm{Na}_{2} \mathrm{SO}_{4}$. Evaporation of the solvent and silica gel column chromatography of the residue using petroleum ether:ethyl acetate (9:1) as eluent afforded silyl ether $7(0.25 \mathrm{~g}, 92 \%)$ as a colorless oil. . [ $\alpha]_{\mathrm{D}}+8.7\left(c 0.6, \mathrm{CHCl}_{3}\right)$; IR (neat) 3210 , 3119, 2931, 2858, 1716, $1472 \mathrm{~cm}^{-1}$; ${ }^{1} \mathrm{H}$ NMR (300 MHz, $\mathrm{CDCl}_{3}$ ) $\delta$ 7.35-7.27 (m, 5H), 6.71-6.50 $(\mathrm{m}, 1 \mathrm{H}), 4.10(\mathrm{~d}, J=6.0 \mathrm{~Hz}, 1 \mathrm{H}), 3.80(\mathrm{t}, J=5.7 \mathrm{~Hz}, 1 \mathrm{H}), 3.47(\mathrm{t}, J=6.3 \mathrm{~Hz}, 2 \mathrm{H}), 3.25-3.10(\mathrm{~m}$, $1 \mathrm{H}), 1.80-1.34(\mathrm{~m}, 6 \mathrm{H}), 0.92(\mathrm{~s}, 9 \mathrm{H}), 0.89(\mathrm{~s}, 9 \mathrm{H}), 0.19-0.07(\mathrm{~m}, 12 \mathrm{H}) ;{ }^{13} \mathrm{C} \mathrm{NMR}(100 \mathrm{MHz}$, $\left.\mathrm{CDCl}_{3}\right) \delta 173.7,138.4,128.4,127.6,127.5,80.6,77.9,73.0,69.9,58.6,33.3,29.5,15.9,25.8$, 22.6, 18.3, 17.9, -4.0,-4.1,-4.4,-4.7; HRMS for $\mathrm{C}_{27} \mathrm{H}_{49} \mathrm{NO}_{4} \mathrm{Si}_{2}+\mathrm{Na}$ calcd 530.3098; found 530.3100 .

To a solution of 7(0.24 g, $0.47 \mathrm{mmol})$ in dry EtOAc $(5 \mathrm{~mL})$ was added $\mathrm{Pd} / \mathrm{C}(50 \mathrm{mg})$ at room temperature and the mixture was stirred for $2 \mathrm{~h}$ under hydrogen atmosphere (balloon) at the same 
temperature. It was then filtered through a short pad of celite and the celite pad was washed with EtOAc $(15 \mathrm{~mL})$. Evaporation of solvent followed by column chromatography of residue using petroleum ether:EtOAc (3:7) gave $7(0.18 \mathrm{~g}, 91 \%)$ as a colourless oil. $[\alpha]_{\mathrm{D}}+11.0(c$ 0.6, $\mathrm{CHCl}_{3}$ ); IR (neat) 3298, 2932, 2859, 1715, 1472, 1362, 1172, $939 \mathrm{~cm}^{-1} ;{ }^{1} \mathrm{H}$ NMR (300 MHz, $\left.\mathrm{CDCl}_{3}\right) \delta 7.42(\mathrm{bs}, 1 \mathrm{H}), 4.05(\mathrm{~d}, J=5.4 \mathrm{~Hz}, 1 \mathrm{H}), 3.77(\mathrm{t}, J=5.4 \mathrm{~Hz}, 1 \mathrm{H}), 3.60(\mathrm{t}, J=5.7 \mathrm{~Hz}, 2 \mathrm{H})$, 3.25-3.17 (m, 1H), 2.38 (bs, 1H), 1.71-1.36 (m, 6H), $0.88(\mathrm{~s}, 9 \mathrm{H}), 0.85(\mathrm{~s}, 9 \mathrm{H}), 0.15-0.05$ (m, $12 \mathrm{H}) ;{ }^{13} \mathrm{C} \mathrm{NMR}\left(75 \mathrm{MHz}, \mathrm{CDCl}_{3}\right) \delta 174.2,80.6,78.1,62.2,58.8,33.0,32.2,25.9,25.7,22.0$, 18.2, 17.9, 4.0, -4.1, -4.4, -4.7; HRMS for $\mathrm{C}_{20} \mathrm{H}_{43} \mathrm{NO}_{4} \mathrm{Si}_{2}+\mathrm{Na}$ calcd 440.2628; found 440.2628.

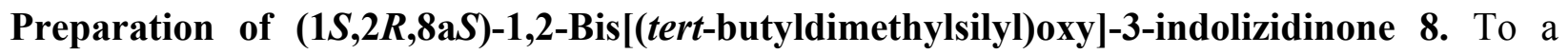
solution of $7(0.16 \mathrm{~g}, 0.38 \mathrm{mmol})$ in dry $\mathrm{CH}_{2} \mathrm{Cl}_{2}(8 \mathrm{~mL})$ were added $\mathrm{Et}_{3} \mathrm{~N}(0.08 \mathrm{~mL}, 0.57 \mathrm{mmol})$ and $\mathrm{MsCl}(0.04 \mathrm{~mL}, 0.57 \mathrm{mmol})$ at $0{ }^{\circ} \mathrm{C}$, and the mixture was stirred at the same temperature. Progress of the reaction was monitored by TLC and after the reaction was complete ( $\sim 45 \mathrm{~min})$, it was quenched by addition of water $(10 \mathrm{~mL})$. It was then extracted with ether $(3 \times 15 \mathrm{~mL})$ and the combined ethereal extracts were washed with brine $(15 \mathrm{~mL})$ and dried over anhydrous $\mathrm{Na}_{2} \mathrm{SO}_{4}$. Evaporation of solvent yielded the crude mesylate, which was subjected to the next reaction without further purification.

To a slurry of $\mathrm{NaH}$ (61 mg of $60 \%$ suspension in mineral oil, $1.53 \mathrm{mmol}$ ) in dry THF (3 mL) was added above crude mesylate dissolved in dry $\mathrm{THF}(4 \mathrm{~mL})$ at $0{ }^{\circ} \mathrm{C}$. The reaction mixture was gradually warmed to room temperature and stirred for $2 \mathrm{~h}$. After completion of the reaction ( TLC) it was cooled to $0{ }^{\circ} \mathrm{C}$ and cautiously quenched by addition of saturated $\mathrm{NH}_{4} \mathrm{Cl}$ solution. It was then extracted with ether $(3 \times 15 \mathrm{~mL})$. Combined ethereal extracts were washed with brine $(15 \mathrm{~mL})$ and dried over anhydrous $\mathrm{Na}_{2} \mathrm{SO}_{4}$. Evaporation of the solvent followed by silica gel column chromatography of the resulting residue with petroleum ether:EtOAc (8:2) as an eluent yielded $8(112 \mathrm{mg}, 73 \%)$ as a colourless oil. $\left.[\alpha]_{\mathrm{D}}+50.2(c) 2.3, \mathrm{CHCl}_{3}\right)$; [lit. ${ }^{2 \mathrm{~g}}[\alpha]_{\mathrm{D}}+47.7(c 1.75$, $\left.\left.\mathrm{CHCl}_{3}\right)\right]$; IR (neat) 2931, 2888, 2858, 1717, 1473, 1387, $1257 \mathrm{~cm}^{-1} ;{ }^{1} \mathrm{H}$ NMR (400 MHz, $\left.\mathrm{CDCl}_{3}\right)$ $\delta 4.14(\mathrm{dd}, J=4.9,1.1 \mathrm{~Hz}, 1 \mathrm{H}), 4.11-4.06(\mathrm{~m}, 1 \mathrm{H}), 3.78(\mathrm{t}, J=6.3 \mathrm{~Hz}, 1 \mathrm{H}), 3.01$ (ddd, $J=8.4$, 4.4, $2.8 \mathrm{~Hz}, 1 \mathrm{H}), 2.61-2.53(\mathrm{~m}, 1 \mathrm{H}), 2.08-2.00(\mathrm{~m}, 1 \mathrm{H}), 1.91-1.86(\mathrm{~m} \mathrm{1H}), 1.70-1.65(\mathrm{~m}, 1 \mathrm{H})$, 1.43-1.29 (m, 2H), 1.18-1.10 (m, 1H), $0.92(\mathrm{~s}, 9 \mathrm{H}), 0.89(\mathrm{~s}, 9 \mathrm{H}), 0.22-0.08(\mathrm{~m}, 12 \mathrm{H}) ;{ }^{13} \mathrm{C} \mathrm{NMR}$ $\left(100 \mathrm{MHz}, \mathrm{CDCl}_{3}\right) \delta 170.1,80.9,78.2,59.5,39.4,30.5,25.8,25.7,24.0,23.3,18.3,17.8,-4.0,-$ 4.1, -4.2, -4.7; HRMS for $\mathrm{C}_{20} \mathrm{H}_{41} \mathrm{NO}_{3} \mathrm{Si}_{2}+\mathrm{Na}$ calcd 422.2523; found 422.2513.

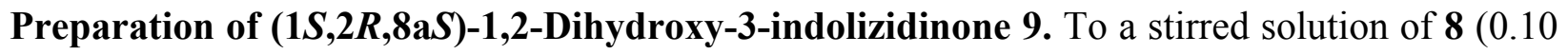
$\mathrm{g}, 0.25 \mathrm{mmol})$ in $\mathrm{MeOH}(3 \mathrm{~mL})$ was added dropwise conc. $\mathrm{HCl}(0.5 \mathrm{~mL})$ and stirred at room temperature for $3 \mathrm{~h}$. After completion of the reaction it was quenched by addition of ammonia solution, filtered through a pad of celite, and concentrated under reduced pressure. Purification of the resulting residue by chromatography on silica gel $\left(8: 1, \mathrm{CH}_{2} \mathrm{Cl}_{2} / \mathrm{MeOH}\right)$ afforded 9 (35 mg, 82 $\%)$ as a white solid. mp $134-135{ }^{\circ} \mathrm{C} ;[\alpha]_{\mathrm{D}}+55.0(c 1.2, \mathrm{MeOH})\left[\right.$ lit. $^{2 \mathrm{~g}} \mathrm{mp} 136-137{ }^{\circ} \mathrm{C} ;[\alpha]_{\mathrm{D}}+52.3(c$ 1.99, MeOH)]; IR (KBr) 3444, 2963, 2871, 1682, 1460, 1278, $1026 \mathrm{~cm}^{-1} ;{ }^{1} \mathrm{H}$ NMR (400 MHz, $\left.\mathrm{CD}_{3} \mathrm{OD}\right) \delta 4.10-4.00(\mathrm{~m}, 2 \mathrm{H}), 3.71(\mathrm{t}, J=6.8 \mathrm{~Hz}, 1 \mathrm{H}), 3.15-3.09(\mathrm{~m}, .1 \mathrm{H}), 2.74-2.66(\mathrm{~m}, 1 \mathrm{H})$, 2.19-2.14 (m, 1H), 1.94-1.89 (m, 1H), 1.79-1.74 (m, 1H), 1.54-1.14 (m, 4H); ${ }^{13} \mathrm{C}$ NMR $(75$ 
$\left.\mathrm{MHz}, \mathrm{CDCl}_{3}\right) \delta 173.1,81.1,77.7,60.6,40.8,31.8,25.4,24.2$; HRMS for $\mathrm{C}_{8} \mathrm{H}_{13} \mathrm{NO}_{3}+\mathrm{Na}$ calcd 194.0793; found 194.0790.

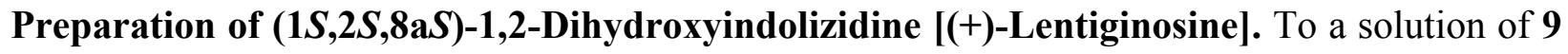
(30 mg, $0.17 \mathrm{mmol})$ in dry THF $(3 \mathrm{~mL})$ was added $\mathrm{LiAlH}_{4}(27 \mathrm{mg}, 0.7 \mathrm{mmol})$ at $0{ }^{\circ} \mathrm{C}$ and the resulting mixture was refluxed for $4 \mathrm{~h}$. It was then cautiously quenched by careful addition of water $(0.5 \mathrm{~mL})$ and $1 \mathrm{~N} \mathrm{NaOH}(0.5 \mathrm{~mL})$ at $0{ }^{\circ} \mathrm{C}$. The resulting mixture was filtered through a pad of celite and concentrated under reduced pressure. The residue thus obtained was purified by chromatography on silica gel $\left(40: 8: 1, \mathrm{CHCl}_{3} / \mathrm{MeOH} / \mathrm{NH}_{3}\right)$ to give (+)-Lentiginosine (24 mg, 87 \%) as a white solid. mp: $104-105{ }^{\circ} \mathrm{C} ;[\alpha]_{\mathrm{D}}+3.3(c 0.7, \mathrm{MeOH}) ;\left[\mathrm{lit}^{2 \mathrm{~g}} \mathrm{mp} 106{ }^{\circ} \mathrm{C} ;[\alpha]_{\mathrm{D}}+3.0(c\right.$ 0.7, MeOH)]; IR (KBr) 3391, 2930, 2733, 1455, 1142, $779 \mathrm{~cm}^{-1} ;{ }^{1} \mathrm{H}$ NMR (400 MHz, CD 3 OD) $\delta$ 3.96-3.91 (m, 1H), $3.59(\mathrm{dd}, J=8.5,3.4 \mathrm{~Hz}, 1 \mathrm{H}), 2.95(\mathrm{~d}, J=10.8 \mathrm{~Hz}, 1 \mathrm{H}), 2.85(\mathrm{~d}, J=10.5$ $\mathrm{Hz}, 1 \mathrm{H}), 2.53(\mathrm{dd}, J=10.5,7.2 \mathrm{~Hz}, 1 \mathrm{H}), 2.04-1.91(\mathrm{~m}, 2 \mathrm{H}), 1.85-1.73(\mathrm{~m}, 2 \mathrm{H}), 1.66-1.51(\mathrm{~m}$, 2H), 1.31-1.19 (m, 2H); ${ }^{13} \mathrm{C}$ NMR (100 MHz, $\left.\mathrm{CD}_{3} \mathrm{OD}\right) \delta$ 85.1, 77.5, 71.0, 62.8, 54.4, 29.3, 25.6, 24.9; Analysis calcd for C 61.12 H 9.62 N 8.91 ; found C 60.85 H 9.37 N 9.22; HRMS for $\mathrm{C}_{8} \mathrm{H}_{15} \mathrm{NO}_{2}+\mathrm{H}$ calcd 158.1181; found 158.1177.

\section{Acknowledgements}

We thank DST, New Delhi for funding of this project. KRP thanks DST, New Delhi for Swarnajayanthi fellowship. ABP thanks CSIR for a senior research fellowship.

\section{References and Notes}

1. Pastuszak, I.; Molynuex, R. J.; James, L. -F.; Elbein, A. D. Biochemistry 1990, 29, 1886.

2. For a review on aminosugars see: (a) Stutz, A. E. Iminosugars as Glycosidase Inhibitors: Nojirimycin and Beyond; Wiley-VCH, 1999. (b) Asano, N.; Nash, R. J.; Molyneux, R. J.; Fleet, G.W. J. Tetrahedron: Asymmetry 2000, 11, 1645. (c) Asano, N. Glycobiology 2003, 13, 93R. For recent synthesis of (+)-lentiginosine see (d) Alam, M. A.; Vankar, Y. D. Tetrahedron Lett, 2008, 49, 5534. (e) Chen, M. J.; Tsai, Y. M. Tetrahedron Lett. 2007, 48, 6271. (f) Cardona, F.; Moreno, G.; Guarna, F.; Vogel, P.; Schuetz, C.; Merino, P.; Goti, A. J. Org. Chem. 2005, 70, 6552. (g) Raghavan, S.; Sreekanth, T. Tetrahedron: Asymmetry 2004, 15, 565. (h) Feng, Z. H.; Zhou, W. S. Tetrahedron Lett. 2003, 44, 497. (i) Rabiczko, J.; Urban, L. Z.; Chmielewski, M. Tetrahedron 2002, 58, 1433. (j) Ha, D. C.; Yun, C. S.; Lee, Y. J. Org. Chem. 2000, 65, 621.

3. For a general approach to the synthesis of $\gamma$-keto amides from tartaric acid see: (a) Prasad, K. R.; Chandrakumar, A. Tetrahedron 2007, 63, 1798. For recent application of $\gamma$-keto amides derived from tartaric acid in natural product synthesis see: (b) Prasad, K. R.; Gholap, S. L. J. Org. Chem. 2008, 73, 2. (c) Prasad, K. R.; Gholap, S. L. J. Org. Chem. 2008, 73, 
2916. (d) Prasad, K. R.; Swain, B. Tetrahedron: Asymmetry 2008, 19, 1134. (e) Prasad, K. R.; Gandi, V. Tetrahedron: Asymmetry 2008, 19, 2616. (f) Prasad, K. R.; Chandrakumar, A. J. Org. Chem. 2007, 72, 6312. (g) Prasad, K. R.; Dhaware, M. Synthesis, 2007, 3697. (h) Prasad, K. R.; Gholap, S. L. J. Org. Chem. 2006, 71, 3643.

4. Formation of a minor amount $(8 \%)$ of diketone resulting from the addition of Grignard reagent to both amide groups is observed.

5. The minor diastereomeric lactam is separable at this stage by column chromatography. No efforts were made to isolate and characterize the very small amounts of minor diastereomer. 